\title{
A Rare Anole on the Isla de la Juventud, Cuba
}

\author{
Antonio Cádiz ${ }^{1}$ and David J. Bird ${ }^{2}$
}

${ }^{1}$ Facultad de Biología, Universidad de La Habana, Ciudad de La Habana (cadiz@fbio.uh.cu)

${ }^{2}$ Department of Applied Sciences, Faculty of Health \& Life Sciences, University of West of England, BA16 1QY (david.bird@uwe.ac.uk)

T The Spiny Anole (Anolis loysianus) is a rare Cuban endemic of the A. angusticeps clade (Nicholson et al. 2005). This species is a trunk ecomorph (Losos 2009), and occurs primarily in shaded microhabitats in well-preserved forests. This lizard has a broad but scattered distribution along the main island of Cuba (Schettino 1999), but has never previously been recorded on the Isla de la Juventud, the second largest island in the Cuban archipelago.

Punta Francés National Park is a protected area in the southwestern portion of Isla de la Juventud. The park contains relatively undisturbed semi-deciduous dry forest on shallow limestone soils over karst. In March 2011, we collected a female Anolis loysianus in the vicinity of the only known cave in the park $\left(21^{\circ} 34^{\prime} 39^{\prime \prime} \mathrm{N}, 83^{\circ} 09^{\prime} 54^{\prime \prime} \mathrm{W}\right)$. The presence of many spine-like scales on the body, limbs, and tail allowed us to identify the species (Schettino 1999). The lizard was observed at $1030 \mathrm{~h}$, head down on the shaded side of a tree trunk, $2.01 \mathrm{~m}$ above the ground.

After collection, the lizard was photographed and held in a plastic bag, where it laid two whitish eggs (laying interval was not recorded). The eggs were placed on damp soil in a plastic container and incubated at approximately $28^{\circ} \mathrm{C}$. One of the eggs approximately doubled in size and subsequently hatched after 40 days. The adult female is now located in the Herpetological Collection of the Museo Nacional de Historia Natural de Cuba (MNHNCu 4710). The juvenile was euthanized nine days after hatching and is now deposited in the herpetological collection of the Graduate School of Live Science, Tohoku University, Japan (ACD 174).

Despite extensive searching over several days, no further individuals of $A$. loysianus were located. This might be attributable to the remarkably cryptic coloration and pattern or to the species' tendency to occur on trunks high in the forest canopy. Other species of Anolis found sympatrically with $A$. loysianus in the same habitat are $A$. sagrei, A. homolechis, $A$. alutaceus, $A$. angusticeps, $A$. luteogularis, and $A$. porcatus.

\section{Acknowledgements}

We thank Luis M. Díaz for his useful comments on earlier drafts of this note.
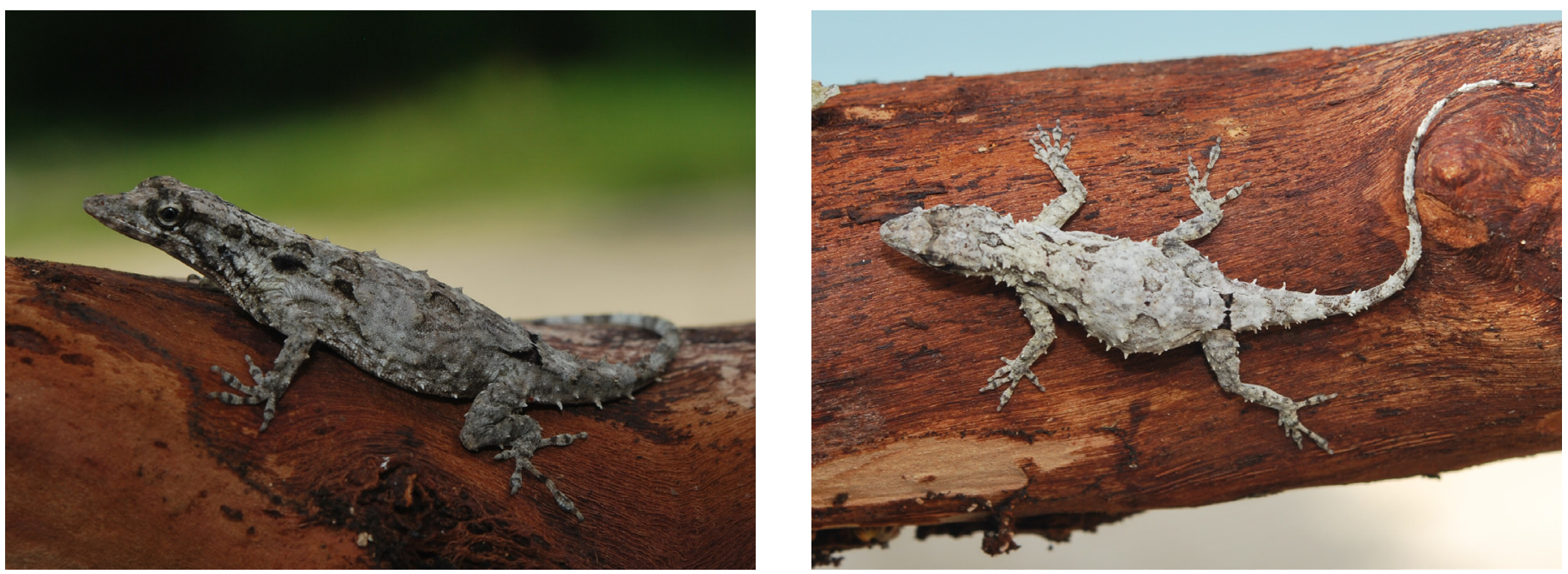

An adult female Anolis loysianus (MNHNCu 4710) from Isla de la Juventud, Cuba; note that the dorsal view clearly reveals its gravid state. 


\section{Literature Cited}

Losos, J.B. 2009. Lizards in an Evolutionary Tree: Ecology and Adaptive Radiation of Anoles. University of California Press, Berkeley.

Nicholson, K.E., R.E. Glor, J.J. Kolbe, A. Larson, S.B. Hedges, and J.B. Losos. 2005.
Mainland colonization by island lizards. Journal of Biogeography 32:929-938.

Rodríguez Schettino, L. (ed.). 1999. The Iguanid Lizards of Cuba. University Press of Florida, Gainesville.
Anolis ecomorphs are the consequences of a spectacular instance of replicate radiations on the large islands of the Greater Antilles. Ernest Williams (1972. The origin of faunas. Evolution of lizard congeners in a complex island fauna: A trial analysis. Evolutionary Biology 6:4789) described six ecomorphs based largely on the nature of the microhabitats used by each form. The categories are crown giant, trunk-crown, trunk, trunk-ground, twig, and grass-bush. Lizards in the same ecomorph category are morphologically similar, but those on different islands are not closely related. Species generally are more closely related to other species on their own island, including those of different ecomorphs, than they are to members of the same ecomorph on other islands. This phenomenon is attributable to parallel and convergent evolutionary events on each island.

The anole ecomorphs are habitat specialists behaviorally and morphologically adapted to use different parts of the environment. The same set of ecomorphs (with several exceptions) has evolved independently on each island in the Greater Antilles. This figure is from Losos (2009) and was based on figures in publications by Stan Rand and Ernest Williams.

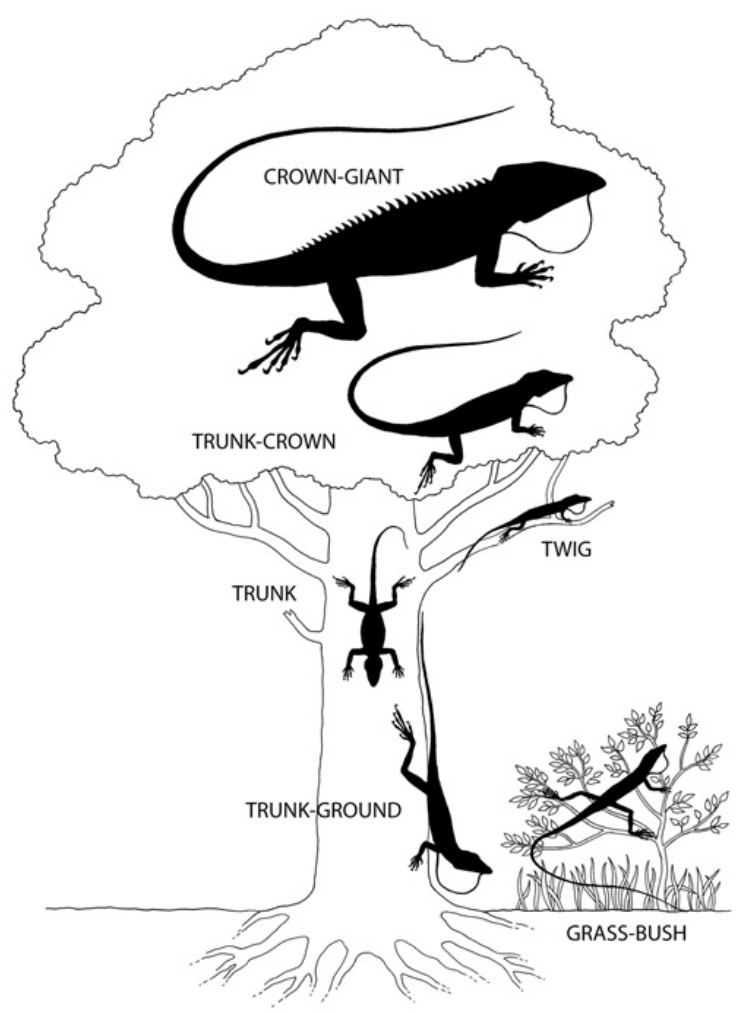

